\title{
ETR Development and Analysis: Case from the Czech Republic \\ Jan Svitlik*
}

\begin{abstract}
:
The paper investigates the effective corporate tax rate (ETR) in the Czech Republic from 2003 to 2013 from the point of both time-series and cross-sectional analysis. We exploit the access to Bureau van Dijk, Amadeus database to get broad data sample from financial statements. Thus, micro backward-looking approach was applied in the paper. We find clear downward trend in the ETR during the given period and statistically significant correlation between the ETR and statutory corporate tax rate (STR). We also undertake analysis of geographical regions using ZIP codes of the companies and analysis of economic sectors according to NACE of the sample firms. Main finding of the cross-sectional analysis is the highest ETR in the region of Prague (capital).
\end{abstract}

Key words: Effective corporate tax rate; Statutory corporate tax rate; the Czech Republic; Time-series analysis; Cross-sectional analysis.

JEL classification: M41, H25.

\section{Introduction}

Economic world has been globalized and interconnected in the past decades to the extent that there are still fewer and fewer constraints in founding business or enlarging business across national borders. Nevertheless, there are and probably will always be differences in national law systems. These distinctions make crossborder business transactions difficult to accomplish. Increasing demand for comparative information among countries is natural consequence of such development. One of the key factors, when deciding about cross-border business transaction or business establishment, is taxation in given country. Due to various constructions of tax base and overall calculation of corporate income tax worldwide, statutory corporate tax rates are very poor indicator of taxation measurement. This fact has led researchers, academics and tax professionals to seeking better indicators which would proxy all characteristics of national tax systems in better way. One of the most commonly used measure is effective corporate tax rate (hereafter ETR). As mentioned for instance by Holečková (2011), statutory corporate tax rates do not take into account depreciation and

Jan Svitlík; University of Economics, Prague, Faculty of Finance and Accounting, Dep. of Financial Accounting and Auditing, nám. W. Churchilla 4, 13067 Prague 3 - Žižkov, <xsvij10@vse.cz>.

The article is processed as an output of a research project Methods of Earnings Management and its application in European environment registered by the Internal Grant Agency under the registration number F1/83/2014. 
Svitlík, J.: ETR Development and Analysis: Case from the Czech Republic.

other deductions, nor do they consider the effects of inflation. Effective corporate tax rates are designed to correct for these facts.

There are three basic methodology categories of ETR empirical studies according to Nicodème (2001), namely the macro backward-looking approaches, the micro forward-looking approaches and the micro backward-looking approaches. The macro-backward looking approaches use historical data from EU, OECD and national statistic organizations. The data are usually available solely on the national level which is the main constraint and disadvantage of the macro approaches. Micro forward-looking approaches used in contemporary research papers are usually based on EMTR and EATR calculations invented by Devereux and Griffith (1998). The advantage of the micro forward-looking approaches is in the ability of prediction based on presumptions and variables integrated in the calculation. Nevertheless, forward approaches are always challenged by biases stemmed from subjective choice of variables and presumptions. The micro backward-looking approaches use historical data, primarily from financial statements of companies. Nowadays there are several databases available which significantly facilitate and speed up the research. The key advantage of the micro backward-looking approaches is in their particularity and conclusiveness in case of sufficiently broad data sample.

Our research partially follows Mejzlík, Vítek and Roe (2014) by using more detailed data. The authors among others investigate relationship between corporate tax base and accounting profits/losses using mainly data from Ministry of Finance and Czech Statistical Office; therefore, the authors basically undertake macro backward-looking approach while we apply micro backward-looking approach on Czech companies. Another example of macro backward-looking approach is the paper of Piotrowska and Vanborren (2008) who analyse the relation between decreasing statutory corporate tax rate (hereafter STR) and slightly increasing ratio of corporate income tax revenues to GDP within EU from 1995 to 2004. Their research findings show both very complex character of relation among the STR, the ETR and tax revenues and significant differences among EU member states.

Elschner and Vanborren (2009) undertake micro forward-looking research approach and find significant correlation between the STR and the ETR (specifically EATR) within EU countries in 2007. They conclude that the relation between the STR and the EATR differs among EU member states, in most EU countries the EATR is slightly lower than the STR. They also find downward trend of EATRs within EU member states from 1998 to 2007. On the other hand, Široký, Kvíčalová and Valentová (2011) conclude that there is no general relationship between the ETR and the STR within EU countries from 2004 to 2010 but their research suggests such relationship in the Czech Republic, even though they use micro forward-looking approach to measure ETR (specifically EATR). 
Buijink, Janssen and Schols (2000) is the first research paper where micro backward-looking approach has been applied on companies from all $15 \mathrm{EU}$ countries. The authors focus on consolidated financial statements of EU companies from 1990 to 1996 and find even greater differences in the ETRs compared to the STRs within European Union. They describe the ETR as a good proxy for tax incentives provided by particular EU member states. The sample of listed companies they use indicates the median ETR of 10 percentage points below the STR; nevertheless, there are significant differences among countries and the Czech Republic is not present in the sample. Nicodème (2001) comes up with similar inferences: the STR was much higher that the ETR in 11 European countries in 1990, 1992, 1994, 1996 and 1998. Nevertheless, he confesses that his measure of the ETR of EU countries is lower than the one measured by other researchers.

Dyreng, Hanlon and Maydew (2008) investigate 1995-2004 sample of US companies and find some evidence for higher average cash effective tax rate in case of smaller companies compared to the large ones. They measure cash ETR as cash taxes paid divided by pretax income (excluding special items). Avi-Yonah and Lahav (2011) compare the ETR of 100 largest US companies with the ETR of 100 largest EU companies from 2001 to 2010 and conclude that despite much higher average STR in the U.S., the ETR of US companies is comparable to or even slightly lower than the ETR of EU companies. This finding suggests very poor relation between the ETR and the STR.

Heinemann, Overesch and Rincke (2008) examine the STRs of 32 European countries from 1980 to 2007 and conclude that the downward trend of the STRs across Europe is mainly driven by tax competition among European countries. They also find that the Czech Republic has most frequently reduced its STR since 1992 out of all states included. Janíčková (2013) examines ETR in the MoravianSilesian Region in the Czech Republic. She hand-collects data from financial statements of companies incorporated in the geographical region chosen according to given criteria. She uses three different methods to disentangle development of the ETR during and right after financial crisis.

The objective of this paper is to analyse long-term ETR development in the Czech Republic and shed some light on the key determinants of its geographical, sectorial and time variation.

The paper is structured as follows. Section two describes data and methodology applied. Section three contains time-series descriptive statistics and linear regression analysis. Cross-sectional analysis of the data follows in the next section. Section five provides results. Section six concludes. 


\section{Data and methodology}

We exploit the access to Bureau van Dijk, Amadeus database ${ }^{1}$ to follow micro backward-looking methodology and undertake both time-series and cross-sectional empirical research of the ETR in the Czech Republic. We got initial sample of 419,965 firm-years from 2003 to 2013 from the database. The time span has been defined as the broadest period available from the database of Czech companies to fulfil the objective of the research. In the first step we have kept only 12-month financial year unconsolidated data of active firms because calculation of the ETR from consolidated financial statements, non-active firms or non-standard financial years might bias the results. Secondly, firms-years with tax expense or earnings before taxes (hereafter EBT) equal zero, lower than zero or missing were dropped. ${ }^{2}$ In the third step, all firms the financial statements of which are compiled in compliance with IFRS were dropped. ${ }^{3}$ Then we dropped financial and insurance sector firms (NACE 6400-6699) because these institutions are usually subject to different accounting and tax regulation. Finally, we have kept only joint stock companies (a.s.) and limited liability companies (s.r.o.). ${ }^{4}$ Final sample counts 187,339 firm-years. The final sample have been winsorized at $1 \%$ level to eliminate outliers. Details about the initial sample selection are described in Tab. 1. Final sample breakdown to financial years and economic sectors (according to NACE) follow in Tab. 2 and Tab. 3 which both prove balanced distribution of firm-years in time and among economic sectors.

\section{Tab. 1: Adjustments of the sample}

\begin{tabular}{ll}
\hline Sample adjustment & Number of firm years \\
\hline Initial sample & 419,965 \\
Only active firms kept & $-10,175$ \\
Only 12-months fin. years kept & -923 \\
Only unconsolidated data kept & $-80,938$ \\
EBT or TAX missing & $-16,157$ \\
EBT or TAX less than or equal zero & $-115,619$ \\
IFRS data dropped & -271 \\
Only joint stock companies and limited liability companies kept & $-7,826$ \\
\hline
\end{tabular}

1 The access to the database is limited to large and medium-size companies; therefore, small companies are missing in the sample.

2 Calculation of ETR out of non-positive data might mislead the results.

3 EBT and so ETR under Czech national GAAP and under IFRS are basically incomparable.

4 Other forms of business might have different tax regimes regarding corporate income tax. 
European Financial and Accounting Journal, 2015, vol.10, no. 4, pp. 05-18.

\begin{tabular}{ll}
\hline Sample adjustment & Number of firm years \\
\hline Financial institutions dropped & -717 \\
Final sample & 187,339 \\
\hline Source: Authorial computation using Bureau van Dijk, Amadeus database. \\
Tab. 2: Breakdown of the final sample: financial years \\
\hline Financial year & Number of firm years \\
\hline 2003 & 2,252 \\
2004 & 11,763 \\
2005 & 14,265 \\
2006 & 16,789 \\
2007 & 19,495 \\
2008 & 20,537 \\
2009 & 20,097 \\
2010 & 21,165 \\
2011 & 21,967 \\
2012 & 21,011 \\
2013 & 17,998 \\
\hline
\end{tabular}

Source: Authorial computation using Bureau van Dijk, Amadeus database.

\section{Tab. 3: Breakdown of the final sample: economic sectors}

\begin{tabular}{lll}
\hline Name of the economic sector & NACE $^{\mathbf{5}}$ & Number of firm years $^{\text {Agriculture, forestry and fishing }}$ \\
\hline Mining and quarrying & $01-03$ & 7,438 \\
Manufacturing & $05-09$ & 570 \\
Electricity, gas, steam and air conditioning supply & $10-33$ & 49,896 \\
$\begin{array}{l}\text { Water supply; sewerage; waste management and remediation } \\
\text { activities }\end{array}$ & 35 & 2,407 \\
\hline
\end{tabular}

5 NACE abbreviation stands for statistical classification of economic activities in the European Community. We use first two out of four digits of NACE to determine the most general economic classification in the Czech Republic. 
Svitlík, J.: ETR Development and Analysis: Case from the Czech Republic.

\begin{tabular}{|c|c|c|}
\hline Name of the economic sector & NACE ${ }^{6}$ & Number of firm years \\
\hline Construction & $41-43$ & 22,050 \\
\hline $\begin{array}{l}\text { Wholesale and retail trade; repair of motor vehicles and } \\
\text { motorcycles }\end{array}$ & $45-47$ & 49,768 \\
\hline Transporting and storage & $49-53$ & 7,890 \\
\hline Accommodation and food service activities & $55-56$ & 2,771 \\
\hline Information and communication & $58-63$ & 7,010 \\
\hline Financial and insurance activities & $64-66$ & 0 \\
\hline Real estate activities & 68 & 7,905 \\
\hline Professional, scientific and technical activities & $69-75$ & 13,750 \\
\hline Administrative and support service activities & $77-82$ & 6,336 \\
\hline $\begin{array}{l}\text { Public administration and defence; compulsory social } \\
\text { security }\end{array}$ & 84 & 29 \\
\hline Education & 85 & 1,476 \\
\hline Human health and social work activities & $86-88$ & 3,219 \\
\hline Arts, entertainment and recreation & $90-93$ & 1,031 \\
\hline Other activities & $94-99$ & 822 \\
\hline
\end{tabular}

Source: Authorial computation using Bureau van Dijk, Amadeus database.

Szarowská (2011) mentions three different approaches how to measure the ETR as the ratio of corporate tax expense (hereafter TAXES) and a denominator which might be (1) EBT, (2) turnover, or (3) gross operating profit/loss. In compliance with Szarowská (2011) we conclude that the most appropriate measure of the ETR in case of domestic analysis and comparison with statutory corporate tax rate is the first approach, i.e. TAXES divided by EBT. Therefore, we apply this approach in calculation of the ETR. We compute the ETR as arithmetic mean of individual firm-year ETRs.

6 NACE abbreviation stands for statistical classification of economic activities in the European Community. We use first two out of four digits of NACE to determine the most general economic classification in the Czech Republic. 


\section{Time-series analysis of the ETR}

Statutory corporate tax rates have been falling in the last two decades in almost all European member states of $\mathrm{OECD}^{7}$ (OECD, 2013). On the other hand, Elschner and Vanborren (2009) suggest that tax base was broadened and other tax reforms took place in nearly all EU member states which might partly or fully offset such decrease in the STR. Therefore, it is not clear, whether the ETR has also decreased during the last two decades, remained more or less unchanged, or even increased. There has been no thorough investigation made in the Czech Republic so far.

This leads us to development of the first hypothesis (H1):

The ETR changed significantly from 2003 to 2013 in the Czech Republic.

In case $\mathrm{H} 1$ holds, we form the second hypothesis (H2) as follows:

Correlation between the ETR and the STR is significant.

\subsection{H1: The ETR changed significantly from 2003 to 2013 in the Czech Republic.}

To investigate H1, we apply descriptive statistics to year-ETRs from 2003 to 2013. See Tab. 4 for the details. We find a clear downward trend in the ETR in the Czech Republic from $37.2 \%$ in 2003 to $26.5 \%$ in 2013, i.e. decrease of more than 10 percentage points, as depicts Fig. 1. The change in the ETR is statistically different from zero; therefore, we cannot reject $\mathrm{H} 1$ at neither $5 \%$ nor $1 \%$ significance level. There has been constant decrease in the ETR during the whole observed period except for 2010-2011. Due to the drop of 3.6 percentage points in 2010, slight increase in the ETR followed in 2011 and 2012. This might have been caused primarily by extraordinary depreciation of assets purchased from 1.1.2009 to 30.6.2010 as a direct reaction of Czech tax authorities to the financial crisis.

\section{Tab. 4: ETR and STR development 2003-2013}

\begin{tabular}{llll|l}
\hline Financial year & Mean (\%) & Std. deviation & Number of firm years & STR $(\%)$ \\
\hline 2003 & 37.2 & 0.76 & 2,252 & 31.00 \\
2004 & 36.8 & 10.25 & 11,763 & 28.00 \\
2005 & 37.0 & 20.07 & 14,265 & 26.00 \\
2006 & 32.7 & 1.00 & 16,789 & 24.00 \\
2007 & 30.5 & 0.89 & 19,495 & 24.00 \\
\hline
\end{tabular}

\footnotetext{
${ }^{7}$ The only exceptions are Hungary and Norway where statutory tax rates have been fairly stable.
} 
Svitlík, J.: ETR Development and Analysis: Case from the Czech Republic.

\begin{tabular}{llll|l}
\hline Financial year & Mean $(\boldsymbol{\%})$ & Std. deviation & Number of firm years & STR $(\%)$ \\
\hline 2008 & 30.2 & 10.51 & 20,537 & 21.00 \\
2009 & 30.1 & 20.77 & 20,097 & 20.00 \\
2010 & 26.5 & 0.73 & 21,165 & 19.00 \\
2011 & 27.7 & 10.38 & 21,967 & 19.00 \\
2012 & 27.9 & 0.98 & 21,011 & 19.00 \\
2013 & 26.5 & 0.77 & 17,998 & 19.00 \\
\hline
\end{tabular}

Source: Authorial computation using Bureau van Dijk, Amadeus database.

Note: $\mathrm{ETR}=$ effective corporate tax rate; STR = statutory corporate tax rate.

\section{Fig. 1: ETR and STR development 2003-2013 (in \%)}

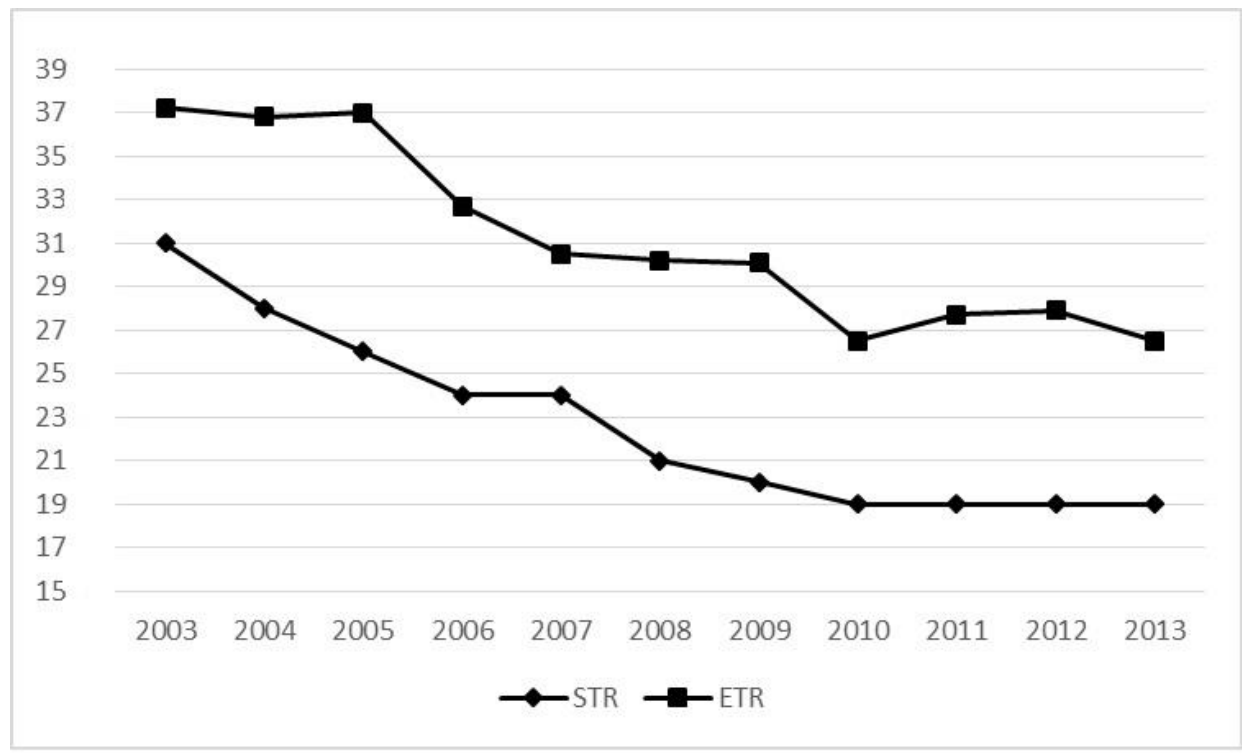

Source: Authorial computation using Bureau van Dijk, Amadeus database.

Note: $\mathrm{ETR}=$ effective corporate tax rate; STR = statutory corporate tax rate.

\subsection{H2: Correlation between the ETR and the STR is significant.}

The stable decrease in the ETR in the Czech Republic from 2003 to 2013 leads us to investigation of $\mathrm{H} 2$ through linear regression of the ETR on the STR from 2003 to 2013. We find highly statistically significant correlation between the ETR and the STR during given time span at $1 \%$ significance level; therefore, we are not able to reject $\mathrm{H} 2$ at $1 \%$ significance level. See Tab. 5 for linear regression details. We run also untabulated test of Spearman's rank correlation for the greater 
robustness of our inferences and find Spearman's rho of 0.9676 which confirms highly significant correlation. The high correlation between the ETR and the STR suggests that there is significant impact of the STR stated by Czech tax authorities on real tax expense of companies proxied by the ETR. Therefore, this fact indicates lower impact of tax base broadening on the ETR than one would expect.

\section{Tab. 5: ETR regressed on STR}

\begin{tabular}{|c|c|c|c|c|c|}
\hline Source & SS & df & MS & & Number of obs $=11$ \\
\hline Model & 153.168637 & 1 & 153.168637 & & $F(1,9)=68.58$ \\
\hline Residual & 20.1004541 & 9 & 2.23338379 & & Prob $>F=0.0000$ \\
\hline \multirow[t]{3}{*}{ Total } & 173.269091 & 10 & 17.3269091 & & R-squared $=0.8840$ \\
\hline & & & & & Adj R-squared $=0.8711$ \\
\hline & & & & & Root MSE $=1.4945$ \\
\hline ETR & Coef. & Std. Err. & $\mathrm{t}$ & $P>|t|$ & [99\% Conf. Interval] \\
\hline STR & 0.9324045 & 0.11259 & 8.28 & 0 & $0.5665044 \quad 1.298305$ \\
\hline _cons & 9.999897 & 2.598241 & 3.85 & 0.004 & $1.55604 \quad 18.44375$ \\
\hline
\end{tabular}

Source: Authorial computation using Bureau van Dijk, Amadeus database and Stata. Note: ETR = effective corporate tax rate; STR = statutory corporate tax rate.

\section{Cross-sectional analysis of the ETR}

\subsection{Analysis of geographical regions}

From the point of cross-sectional analysis we undertake investigation of the ETR among seven geographical regions of the Czech Republic according to ZIP codes ${ }^{8}$ of firms from Bureau van Dijk, Amadeus database. These regions are namely Prague (capital), Central Bohemia, Southern \& Western Bohemia, Northern Bohemia, Eastern Bohemia, Southern Moravia and Northern Moravia.

There has been published the information about very low probability of tax audit in Prague and other Czech cities due to the high number of incorporated firms there compared to other regions in the Czech Republic (Vlková, 2009). This fact indicates that companies incorporated in Prague might be more tax aggressive and therefore have lower ETRs because they are less likely to face tax audit if incorporated in Prague. We do not find any evidence from the empirical data for such a claim. On the contrary, the weighted-average ETR (2003-2013) of firms

8 ZIP codes in the Czech Republic consist of five digits. The first digit determines one of seven geographical regions of the Czech Republic. 
Svitlík, J.: ETR Development and Analysis: Case from the Czech Republic.

incorporated in Prague (33.4\%) is higher than the weighted-average ETR of firms incorporated in all other regions (27.6-30.9\%) as depicts Fig. 2.

Moreover, in untabulated analysis we find that the ETR was the highest in Prague region for 8 years out of 11 observed years. In remaining 3 years, Prague was always on the second place in terms of the highest ETR. Therefore, companies incorporated in Prague does not seem to be more tax aggressive according to the ETR than companies from other Czech regions.

\section{Fig. 2: Weighted-average ETR (2003-2013) among geographical regions}

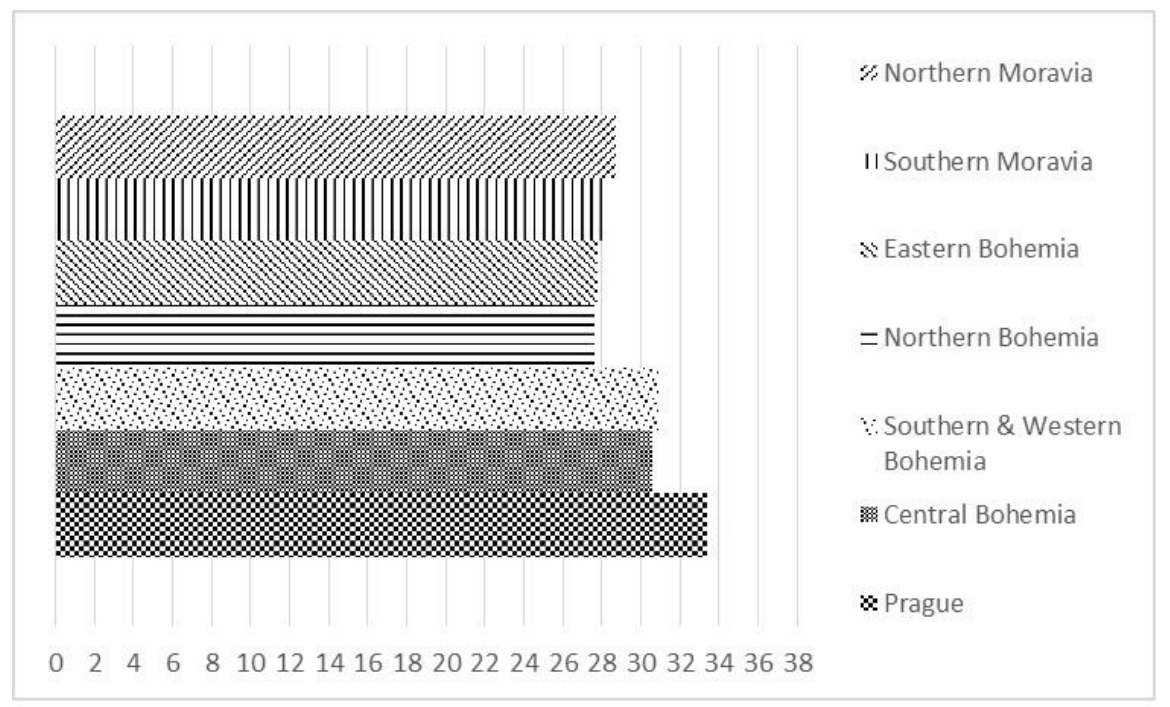

Source: Authorial computation using Bureau van Dijk, Amadeus database.

\subsection{Analysis of economic sectors}

As a next step within cross-sectional analysis, we use NACE of all sample firms and investigate the ETR among economic sectors. The lowest weighted-average ETR from 2003 to 2013 is found within sectors Electricity, gas, steam and air conditioning supply (27.7\%), Water supply; sewerage; waste management and remediation activities (27.9\%), and Human health and social work activities (27.9\%). On the contrary, we find the highest weighted-average ETR from 2003 to 2013 within sectors Accommodation and food service activities (36.8\%), Public administration and defence; compulsory social security (35.0\%), and Transporting and storage (34.4\%). Find detailed information in Tab. 6. These inferences do not fully hold with those of Nicodème (2001) who finds the lowest ETR within sectors Energy and Water and Transport when investigated 11 EU countries from 1990 to 1999 . There might be basically three reasons for such inconsistency. First, Nicodème uses slightly different classification of economic 
European Financial and Accounting Journal, 2015, vol.10, no. 4, pp. 05-18.

sectors; second, the period of our research does not overlap the research period of Nicodème; third the Czech Republic is not covered in paper of Nicodème and as we see from other relevant research papers, there are significant differences across European countries.

Tab. 6: ETR among economic sectors

\begin{tabular}{lll}
\hline NACE & Weighted-average ETR 2003-2013 & Number of observations \\
\hline $01-03$ & 28.9 & 7,438 \\
$05-09$ & 28.0 & 570 \\
$10-33$ & 29.6 & 49,896 \\
35 & 27.7 & 2,407 \\
$36-39$ & 27.9 & 2,971 \\
$41-43$ & 29.7 & 22,050 \\
$45-47$ & 29.8 & 49,768 \\
$\mathbf{4 9 - 5 3}$ & $\mathbf{3 4 . 4}$ & $\mathbf{7 , 8 9 0}$ \\
$\mathbf{5 5 - 5 6}$ & $\mathbf{3 6 . 8}$ & $\mathbf{2 , 7 7 1}$ \\
$58-63$ & 31.0 & 7,010 \\
$64-66$ & 0.0 & 0 \\
68 & 32.3 & 7,905 \\
$69-75$ & 30.9 & 13,750 \\
$77-82$ & 29.6 & 6,336 \\
$\mathbf{8 4}$ & $\mathbf{3 5 . 0}$ & $\mathbf{2 9}$ \\
85 & 29.3 & 1,476 \\
$86-88$ & 27.9 & 3,219 \\
$90-93$ & 32.6 & 1,031 \\
$94-99$ & 33.2 & 822 \\
\hline $5045: A 4 h$ &
\end{tabular}

Source: Authorial computation using Bureau van Dijk, Amadeus database.

Note: Three lowest weighted-average ETR observation in italics, three highest in bold. NACE 64-66 (Financial and insurance activities) dropped from the sample due to nonstandard characteristics. 


\section{Results}

We analyse long-term development of the ETR in the Czech Republic both from the time-series and the cross-sectional point of view. Primarily, we find the trend, the stable downward trend of the ETR from 2003 to 2013. Despite the financial crisis, declining slope of the ETR is clear for the whole observed time span.

As mentioned by Heinemann, Overesch and Rincke (2008), the STR changed significantly in the Czech Republic during given period and indeed, we find statistically significant correlation between the ETR and the STR.

The analysis of geographical regions within the Czech Republic shows us that there are basically three ETR-distinct areas. The lowest ETR is concentrated in Moravia, Eastern Bohemia and Northern Bohemia. Southern \& Western Bohemia and Central Bohemia are regions of medium height ETR. As we find unambiguously highest ETR in Prague (capital), these empirical findings seem to be inconsistent with the claim that Prague and other Czech cities are potential "tax havens" due to very unlikely tax audits. Or at least, our research inferences do not indicate high concentration of tax aggressive firms in Prague.

The analysis of economic sectors according to NACE indicates relatively equal ETR distribution across majority of sectors in the Czech Republic with the lowest ETR of $27.7 \%$ within Electricity, gas, steam and air conditioning supply and highest ETR of $36.8 \%$ within Accommodation and food service activities. Although the spread of the ETR looks relatively wide, majority of the sectors are characterized by ETR of 28-32\%.

\section{Conclusion}

There has been conducted relatively extensive research of the ETR within Europe, mainly oriented on international comparisons. Also dozens of ETR-topic papers were released in the U.S. Nevertheless, thorough national ETR micro backwardlooking analysis focused on the Czech Republic has been missing so far. We exploit the access to Bureau van Dijk, Amadeus database to undertake both timeseries and cross-sectional analysis of the ETR in the Czech Republic from 2003 to 2013. We find declining trend of the ETR and moreover, strong correlation between the ETR and the STR on the broad sample of Czech companies, which is our main contribution to the existing literature.

We also analyse the ETR from the point of geographical regions and economic sectors which helps us to better understand real impacts of tax incentives and tax enforcement in the Czech Republic. Probably the most important inference of our cross-sectional analysis is the unexpected finding of the highest ETR in the region of Prague. 
Even though we shed some light on the ETR development and characteristics in the Czech Republic, there are still unanswered questions that are not covered in this paper. For instance, firm-size or form of business analysis of the ETR in the Czech Republic are ideas for future research. Our approach to the database is limited to large and medium-size companies; hence, examination of the ETR covering also small companies is another topic for future research.

\section{References}

Avi-Yonah, R. S., Lahav, Y., 2011. The Effective Tax Rate of the Largest US and EU Multinationals. Law \& Economics Working Papers, Paper 41, University of Michigan Law School.

Buijink, W., Jansses, B., Schols, Y., 2000. Evidence of the effect of domicile on corporate average effective tax rates in the European Union. MARC Working Paper MARC-WP/3/2000-11, University of Maastricht, The Netherlands.

Devereux, M. P., Griffith, R., 1999. The Taxation of Discrete Investment Choices, Revision 2. Working Paper Series No. W98/16, The Institute For Fiscal Studies.

Dyreng, S. D., Hanlon, M., Maydew, E. L., 2008. Long-Run Corporate Tax Avoidance. The Accounting Review 1, 61-82.

Elschner, C., Vanborren, W., 2009. Corporate Effective Tax Rates in an Enlarged European Union. European Commission - Taxation and customs union, Luxembourg.

European Commission, 2010. List of NACE codes. 26 March 2010. Available from: <http://ec.europa.eu/competition/mergers/cases/index/nace_all.html>. [20 August 2015].

Heinemann, F., Overesch, M., Rincke, J., 2008. Rate Cutting Reforms and Corporate Tax Competition in Europe. ZEW - Centre for European Economic Research Discussion Paper 08-028.

Holečková, J., 2013. Distorting Effects of Taxation on Assets and Sources of Finance: Effective Tax Rates in the Czech Republic in the Year 2000-2010. Prachalias, Chrysovaladis (ed.). International Conference on Applied Financial Economics. Samos Island, 30.06.2011 - 02.07.2011. Athens: National and Capodistrian University of Athens, 403-410.

Janíčková, L., 2013. Effective Tax Rates in the Moravian-Silesian Region. DANUBE: Law and Economics Review 4, 83-92.

Mejzlík, L., Vítek, L., Roe, J., 2014. Adjustments to Accounting Profit in Determination of the Income Tax Base: Evolution in the Czech Republic. European Financial and Accounting Journal 4, 4-24. 
Svitlík, J.: ETR Development and Analysis: Case from the Czech Republic.

Nicodème, G., 2001. Computing effective corporate tax rates: comparisons and results. European Commission, Directorate General for Economic and Financial Affairs, Brussels.

Nicodème, G., 2007. Do Large Companies Have Lower Effective Corporate Tax Rates? A European Survey. CEB Working Paper No. 07/001, Free University of Brussels - Solvay Business School.

OECD Tax Database, 2013. OECD Corporate Income Tax Rates, 1981-2013. 18 December 2013. Taxfoundation.org. Available from: <http://taxfoundation.org/article/oecd-corporate-income-tax-rates-1981-2013>. [21 August 2015].

Piotrowska, J., Vanborren, W., 2008. The corporate income tax rate-revenue paradox: Evidence in the EU. European Commission - Taxation and customs union, Luxembourg.

Szarowská, I., 2011. Jak vysoké je korporátní daňové zatížení? Acta academica karviniensia 2, 196-207.

Široký, J., Kvíčalová, J., Valentová, I., 2011. Identification of Causes of Differences in Statutory and Effective rates of Corporate Taxes. Acta Universitatis Agriculturae et Silviculturae Mendelianae Brunensis, 391-397.

Vlková, J., 2009. V Praze vládne daňová pohoda, kontrola z úřadu chodí jednou za sto let. 16 April 2009. idnes.cz. Available from: <http://ekonomika.idnes.cz/vpraze-vladne-danova-pohoda-kontrola-z-uradu-chodi-jednou-za-sto-let-1ik/ekonomika.aspx?c=A090415_230202_ekonomika_anv>. [20 August 2015]. 